\title{
A Trinitarian theology of creation: An ethical perspective
}

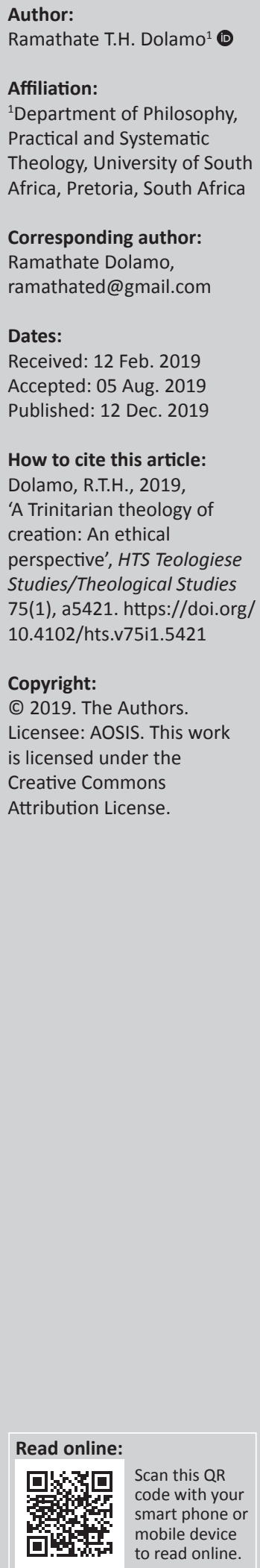

This article discusses factors that have occasioned and precipitated climate change and consequences that resulted from our exploitation and abuse of God's creation. It is argued that from the theological point of view, wrong interpretation of the Bible led us to the ecological crisis that is threatening all life on the planet earth. Assumptions and misconceptions undergirding creation and the cosmos in general are also discussed. Most importantly, theologies of creation that have been operative for centuries are found wanting and in their place a Trinitarian theology is proposed that will include all the three articles of the Christian Creed. It is believed that this theology that includes the cosmic dimension of salvation will make us relate to creation in a more sensitive manner in that as human beings we are kin to nature in most respects and therefore as natural as nature.

Keywords: climate change; ecological crisis; creation; nature; trinity; theology; redemption; cosmic christ; articles of the creed.

\section{Introduction}

We find ourselves in an ecological crisis that is created by us. The consequences of climate change are becoming increasingly devastating, and we are warned that if nothing is done immediately in terms of prevention, mitigation and adaptation, the world will be an intolerable place to live in, especially for the generations to come. All sectors of society such as religion, culture, civilisation and the sciences are to blame and capitalism as well as the free market economy are to receive most of the blame as they pursue wealth at the expense of creation. Greed is insatiable (Johnsen 2009:106; Joseph 2007:7, 2013a:7; Mortensen 1995b:12). But what concerns us most in this study is the role that theology has played and continues to play. Misunderstanding and misinterpretation of the Judeo-Christian scriptures, conscious and sub-conscious, is at the heart of the crisis. Creation stories in Genesis 1 and 2 have been open to abuse to serve the interests of dominant ideologies (Zachariah 2009:88). The original meaning of the creation stories is that humans are God's representative in creation, helping God in God's creative work. That is the significance of the reference to imago Dei and not in the despotic sense. Humans share in the nature of Father-creator, which is wisdom and goodness (Boff 1995:44). The First Article of the Apostles' Creed was not dealt with properly in that God was discussed without sufficient discussion on creation per se. As time passed by, the Second Article was added that unfortunately did not pay enough attention to the redemption of the whole creation; salvation was only limited to Homo sapiens, and much later, the Third Article was added on the theology of creation but the activity of the Holy Spirit was limited to the church and never opened up to the whole creation (Huang 2013:13). A Trinitarian theology that is proposed here is aimed at addressing those deficiencies. It is believed that creation will be taken more seriously and with the sensitivity it deserves.

We are not only natural together with the whole creation, animate and inanimate, but as human beings, we have a special mandate to be stewards of God's creation. We are nature's friends, we work on the land and according to Boff (1995:45), we become angels of nature by safeguarding it. We must learn to live harmoniously with nature for our own sake. The truth of the matter is that we need creation more than it needs us. Boff (2008), however, gives us hope when he says:

... $[A]$ new paradigm is emerging seminally, a paradigm of reconnection, of re-enchantment about nature and of compassion for those who are suffering, one sees a dawn of a renewed tenderness for life and authentic feeling of belonging to the loving Mother Earth. (p. 10)

Although the North is largely responsible for climate change, many of them are not seriously affected by growing climate unpredictability. Those who suffer are primarily those in the South who are the least to blame for the degradation of nature (cf. Northcott 2007:61-64). 


\section{Ecological crisis}

According to Boff (1995):

The term 'ecology' was coined in 1866 by the German biologist Ernst Haeckel (1834-1919). It derives from two Greek words, oikos, which means 'house' or 'home', and logos meaning 'reflection' or 'study'. Therefore, ecology means the study of the conditions and relations that make up the habitat (the house) of each and every person and, indeed, organism in nature. (p. 9)

Today this definition has been broadened to cover all things animate and inanimate.

Jon-Ji (1995:77) owns up by confessing that as humans we have messed up God's creation for nature, the atmosphere and all living creatures are on the brink of destruction. This human-caused crisis has resulted in the disruption of the global climate and weather patterns which is the result of mainly the emission of greenhouse gases from burning fossil fuels. Solar radiation entering the atmosphere is trapped, resulting in the warming of the atmosphere, oceans and land and increasing the frequency and intensity of storms, droughts and floods. Sea levels rise and threaten the lives of communities of the coastal areas and definitely the small islands. Climate change results in severe food shortages, conflicts over land and water, forced migration of peoples and other economic and political crises. It is estimated that if immediate action is not taken, 50 years of development gains in poor countries will be permanently lost (Bloomquist 2009:5; see also Bloomquist 2009:13-14). Concentrations of greenhouse gases will more than quadruple by 2100 and by the end of the 21st century, global surface temperature will soar to $4^{\circ} \mathrm{C}$ (Martin-Schramm 2009:34). McDonagh (1986:17-59) fully discusses the threat to life as a result of climate change. The climate change agenda has been discussed for more than four decades globally, but the world seems to be not listening because as Conradie (2009:35) observes, 'carbon emissions have increased and of late, China has joined the United States of America as chief polluters as well as increasing consumption and population levels'.

What I have gathered with many of the scholars I have consulted is that the climate change challenge must be addressed as a matter of urgency. The environmental crisis can no longer be ignored for it affects all creatures and the time to act is now (Bloomquist 2009:5; Mortensen 1995b:12). Lutheran World Federation (LWF) (2009:22) fervently calls for repentance and conversion as a starting point to tackle the crisis. It must be addressed from as many angles as possible, as we try to prevent further damage to the environment, mitigate the consequences of the damage and adapt to the reality of the present conditions. 'Ecological crisis has led humanity to a defining moment. The earth is losing its capacity to sustain biological life' (Joseph 2013a:5). Referring to his book, Boff (2008:1) says, 'This book has been written as a matter of urgency. We see everywhere symptoms, signs of great devastations affecting planet Earth and humankind'. Joseph (2013b:25) goes so far as to declare the ecological crisis a Kairos matter, meaning that it should be elevated to a Status Confessionis. He says (Joseph 2013b):

Humanity is fast approaching to a time for serious introspection; a planetary Kairos where self-examination is warranted from religious leaders, economists and natural scientists in order to identify their role in the ensuing crisis of environment. (p. 25)

This means that everything must be performed in our power and ability to stop the haemorrhage. It is not just a 'mess' that we find ourselves in. It is a catastrophe of astronomical proportions. It is 'human-induced' (Conradie 2009:37) and it is us, the perpetrators, who must become agents of restoring the world to its state of goodness that God had made. It boggles the mind that as humans we were the last of the creatures to be created according to Genesis 1 and 2 and we have caused so much damaged in the history of the cosmos. Natural science tells us that God's creation is between 18 and 20 billion years old (McDonagh 1986:117). But Homo ardipithecus is 4.5 million years old, Homo habilis is 2 million years old, Homo erectus is 1.6 million years old, Homo sapiens arcaicus is 250000 years old and Homo sapiens sapiens is 150000 years old. 'From this last kind, with its completely reflective consciousness, we are the direct descendants' (Boff 2008:108). But what has led us into this crisis as humans made in the likeness and image of God?

\section{Assumptions and misconceptions}

There are some assumptions and misconceptions that have undergirded and driven creation into the crisis in which we find ourselves and these assumptions have led us into bad practices and habits that have put the whole creation at the brink of catastrophe according to LWF (2009:15-16). Let us look at some of the assumptions: (1) God is a transcendent, unchanging heavenly monarch and patriarch who is untouched by earthly realities. Creation is therefore not the concern of God, and humans can do whatever they want with it without being accountable to God. (2) There is a world view that hierarchically put God at the apex of the pyramid followed by men, women, children (Ps 8:5, Heb 2:7) and animals, and then at the bottom, the rest of all creation. This hierarchical order meant that God's creation would be considered the least important, and therefore, it could be exploited for the benefit of humans who are closest to God. (3) Humans have been instructed by God above to dominate creation and to exercise brute power over it. This unlimited power should be exercised for human consumption at the expense of creation (Gen 1 and 2). (4) God acts predominantly in history rather than in creation. This means that God is interested mainly in the affairs of individuals, peoples and nations but not so much in what happens to the other members of creation such as animals and plants. (5) Only humans, specifically Christians, are beneficiaries of God's redemption and grace (Jn 14:6). This mentality paved way to abuse creation and to rob other people who were not Christians of their human dignity. Slavery, for example, was a direct offshoot of such an attitude. (6) The separation of the secular and the spiritual, religion and politics, church and 
state, and so on (Eph 5:7-14) dictated the areas where God would be present and where not. Moreover, creation was such an area where God would be unconcerned.

As alluded to above, these assumptions and misconceptions resulted in bad practices: (1) economic life that was based on endless quests for greater growth and profit driven by greed was developed. Capitalism is known for its creed that nature's resources must be used without limit to the benefit of humanity and at the expense of creation. (2) Dependence on fossil fuel that is not unlimited increased drastically over the last 50 years for purposes of development. This practice obviously does not have the best of the next generations at heart.

It is self-centred and selfish and our children and their children will curse us for giving them the toxic creation we are passing on to them. (3) Slavery and its contemporary colonisation built empires by using Africans and Asians as slaves and cheap labour, while at the same time raw materials and other resources were extracted at an alarming rate by the colonising powers. (4) These assumptions reinforced and perpetuated patriarchal practices globally that placed women, children and the rest of creation under the control of and abuse by men. Women were to become perpetual minors who needed tutelage by men no matter how old they were. (5) Discrimination of the 'other' on the basis of gender, race, ethnicity, caste, economic or political status was the order of the day and this mentality persists until this day, even in the highly developed democracies. (6) Some aspects of creation such as trees, water, animals and air were considered dispensable when we had to choose what to sacrifice at the quest for wealth and profit. (7) The anthropocentric view that could be traced back to the period of the Enlightenment believed that humans as centres or crown of creation can preserve only that was of value for the benefit of humans and everything else can be left to disintegrate.

Consequences of the climate change have made some of us to think that God is no longer active in the world. Some of us are of the view that natural disasters are 'acts of God' and therefore are deserved punishment for our rebellious ways. Therefore, as human beings, there is nothing we can do about them but to simply endure our punishment to the full extent of God's fury and wrath (Rossing 2009):

Traditional village communities throughout the world are cruellest injustice of global climate change: it is the world's poorest people - those who have done the least to cause the problem of climate change - who are the first to suffer its catastrophic effects. (p. 130)

It is absurd to suggest that God punishes these poor people. In law, this would be called double jeopardy. But we should admit that God is somehow involved in these disasters to wake us up from our slumber to the urgency of the environmental crisis. God therefore warns us to do something about the crisis such as prevention, mitigation and adaptation
(LWF 2009:15-16). In the following section, let us examine some of the elements that will help in formulating a theology of creation that would be relevant for the ecological crisis that we face.

\section{Elements of theology of creation}

Hefner (1995) tabulates the elements as follows:

1. 'our kinship with nature is grounded in God's creative act' (Hefner 1995:127). There is no struggle or testing when creation came into being according to the HebrewChristian view, creation simply came into being by God's command and there is no intermediary between God and the creative act of origination. The two Genesis creation stories and creation traditions embedded in the book of Job, the nature Psalms and the gospels attest to this fact. 'Humans are included within the process of originating creation, not apart from it' (Hefner 1995:127). Genesis 2 tells us that humans are made up of dust and have received God's spirit. Sacraments are part of nature that has promise attached to it. This definition tells us that we are either God's paradigm to show how God is present in creation and history or that we fit neatly under the sacramental paradigm that applies to all creation. The Holy Spirit permeates all creation, by giving life to plants, animals, water and capacitates charismatic leaders, responsible for the birth of Jesus Christ and gets poured out upon societies and communities. Creatio ex nihilo proves that there is no other ground for nature's originating than God' and 'This origination takes place under the conditions of God's freedom and intentionality' (Hefner 1995:128).

2. 'On the basis of God's creation work, nature possesses the continuing capacity and suitability to be a vessel of God's presence and an instrument of God's work' (Hefner 1995:128). Even after the Fall, creation's divinity and its usability as an instrument of God's action were not completely destroyed. God's incarnation in Jesus of Nazareth as both divine and human substantiates the importance of creation and its capability, but there is no confusion between the two natures. 'In Jesus, the human remains fully and naturally human, without change, while the divinity is likewise uncompromised' (Hefner 1995:129). Sacramentally, real bread, real wine and real water understood with the promises attached to them have become vehicles for actualising the grace they portray.

3. 'The future of nature is linked with the promise of the Kingdom of God' (129). Jesus did resurrect not only in body but also in spirit. The final stage of nature would be the:

$[R]$ ecapitulation of all creation where nature would be reconciled, animate and inanimate, and the entire creation will be brought to God's fruition, and the creation embraces the whole of the natural world. (Hefner 1995:129-130)

4. 'The shape of human behavior in this created natural order is that of God's created co-creators' (Hefner 1995:130). Humans as natural creatures are created in the 
image of God. Imago Dei refers to human beings as destined to actualise the presence of God within the created order. Humans are made co-creators by the intentionality of the loving God. God has sent us Jesus as our guide (Hefner 1995:131).

5. 'The poignancy of the relationship between humans and the rest of nature is depicted in the cross of Christ' (Hefner 1995:131). There is a sickening naiveté and hypocrisy as to how as humans we are shaped and supported by creation on the one hand, and the reciprocal exploitation that marks all relationships in nature on the other hand, particularly that of humans and the rest of creation. Humans and nature exploit each other and both are vulnerable to each other. Humans' survival depends on the exploitation of creation. 'We have literally scratched our living out of the flesh of our sibling, the earth' (Hefner 1995:132). Mature faith should allow grace to tame creation. There should be no tragedy between humans and creation. The Christian gospel is fundamentally a gospel of transformation, a process that is already taking place through God's grace. Our survival should not depend on the annihilation of creation because that would be suicidal. A theology that would be relevant to the environmental crisis, a theology that cares for the earth, our sibling should be an investiture of the natural world in grace and of ourselves in the implications that flow from that investiture (Hefner 1995:134). The elements of theology of creation that we have discussed above have provoked us to look for new possibilities for conceiving creation in particular and the whole of the cosmos in general, to which we now turn.

\section{New possibilities for conceiving creation}

Since Charles Darwin's work of evolution, so much has come to light ever since, which warrants re-visitation of how creation was conceived. From evolution to genetics and molecular science, relativity theory, quantum mechanics, the thermodynamics of non-equilibrium systems and chaos cosmology including 'big bang' theory, discovery of the Deoxyribonucleic Acid (DNA) molecule, developments in genetics, sociology, palaeontology, primate research and the sciences with information and computers have compelled us to review our relationship with creation. We have a sibling relationship with the eco-sphere and therefore share kinship with nature's past, present and future. Elements of the periodic also form the building blocks of our bodies (Hefner 1995:121). There has been an incredible deepening and expanding of our views of what creation is and what its possibilities are (Hefner 1995:135).

We know today that the cosmos is at least 12 billion years old comprising more than a billion stars, and yet in spite of its vastness, it is infinitely small and that microscopic studies warn us that experience alone cannot be the only source for comprehending it. We share so much DNA with other animal species that each of us is formed by 100000 genes which, in turn, are composed of 3 billion nucleotides (Hefner 1995:
135-136). Everything is understood in terms of evolution: cosmic evolution, terrestrial evolution, the evolution of the organism and of culture. This evolution process accounts for the interrelatedness of all things and humans included. We are thoroughly creatures of nature. Against what we know today with the assistance of modern science and technology, 'The possibilities that have already been actualized in the huge continuum of cosmic and terrestrial evolution make older ideas of transcendence pale in comparison' (Hefner 1995:136).

These new possibilities unearthed by the sciences should help Christian theology to better understand complexities of creation and to influence us in the manner that will make us more sensitive to our relationship with it. Although the relationship between modern sciences and theology is still controversial for both entities, modern sciences reveal what the cosmos is, and theology interprets the study of the modern sciences in terms of God's grace or sacramental presence of God.

The outcomes of the theology of creation discussed above are extremely exciting. (1) Theology and the natural sciences will again trust one another and accept one another's credentials. All misleading and prejudicial stereotypes about each other should be shaken off. (2) We should comfortably talk about ourselves as creatures together with other creatures without the fear of losing our uniqueness as human beings created in the image and likeness of God.

(3) What we are, or what we do and even what our aspirations are as human beings should always and consistently be referred to the processes of creation and to their future. We exist because of the processes of creation, and therefore, a non-instrumental valuation of creation is called for. The life of Jesus and his death serve as our model. (4) A theology of creation:

$[M]$ ust recognize that, in light of our status as a phase of nature's processes, our niche can also be understood as one of preparing for the best possible future for those processes. (Hefner 1995:139)

In our cultural life, we implicate creation in our human adventure. We mould creation as we create culture. The best possible future for us must be pursued in consideration of the future of the cosmos in general and the environment in particular. (5) A theology of creation 'must help us discern the dimension of ultimacy in nature's processes and how to conceptualize them' (Hefner 1995:139). We are in creation the only discerners and conceptualisers of ultimacy and are therefore not worshippers of creation. Species get extinct, but the process of creation's continual transmuting or evolving does not. This transmuting will finally lead to the liberation of all sorts for the whole creation.

\section{Trinity and creation}

One last reinforcing and reintegrating factor in the theology of creation is to embed it in the three Persons of the Trinity. According to Mortensen (1995b:14), 'Creation is the most 
amazing and mysterious handiwork of the Triune God'. Trinity is the narrative of God's historical relationship with God's creation: its time, past, present and future. Creation is an expression of God's love in spite of natural disasters, and decay, human frailty, sin and death. It is, in fact, the thesis and argument of this study that until the three articles of the Creed are taken equally seriously, theology of creation would always be lob-sided and distorted. This kind of theology has resulted into the way we have been relating to creation, a practice that has driven all of creation at the brink of catastrophe. According to Boff (1995):

Ecology is a complex and complete interplay of relations. It includes everything, disregards nothing, values everything, and cares for everything. It relies on the foremost intuition of Christianity: its divine conception. It affirms the one nature of the Godhead, but at the same time maintains the diversity of the divine Persons without in anyway 'multiplying' God as a number of gods. Christianity has always believed that God is Father, Son, and Holy Spirit. This divine Persons co-exist eternally, distinct, united, equally eternal and infinite. They are simultaneously, and there is no precedence among them, no subordination, and no sequence. (p. 48)

Boff (1995:48) asserts that the universe is a reproduction of the Trinity and the Trinity invades every being, enters into every relationship and erupts into every ecosystem. Jon-Ji (1995:79) observes that since the 16th century, Protestantism focused mainly on the Creator than on creation, that is, on God's faithfulness rather than on the order of the world. Thus, full justice was never done to the First Article of the Creed. The discussion on the role of the logos in creation was largely absent, and therefore, people were not conscientised to the sensitivities of creation as a whole. 'In fact, no one can understand Jesus Christ and God's redemptive work through Christ, if he or she does not also understand himself or herself as God's creature' (p. 79).

According to Lonning (1995:40), debates about theology and ecology took a back seat in the last century mainly because of the tensions that erupted between the sciences and those of spiritual and terrestrial life. He appeals to the churches today to develop a theology of creation that will address issues about preservation of the environment and the protection of natural resources. Looking at the First and Second Articles of the Creed, for example, he does not see why there is a confrontation between creation-based and Christologically founded reflection. There are convergences that could be used to craft a theology of creation that would be sensitive to creation. For example (Lonning 1995):

Liberation theologians discovered in process thought an approach to creation with a stress on change and not on givens, on future not on past, and consequently dedicated to transformation not to preservation. It further discovered a God dealing with creatures, not as an omnipotent maker exercising unconditional control of his produce, but as an ultimate mystery of becoming unified with the multitude of its manifestations in shared freedom and dependence. Process theologians on their side learned to expand their vision of the natural world to include, and to emphasize the progressive formation of human society just as much as that of nature. (p. 43)
Nilsson (1995:117) also observes that much of theology has neglected creation and insists that this mistake must be corrected because it is responsible for the way we have been relating with it. According to Hafstad (1995:105), two theologies are especially responsible. Dialectical theology concerned itself with humans' response and understanding of God's revelation through Christ and this theology overshadowed the belief in creation, and theology of secularisation refused to attribute divinity to the work of creation in itself. The theology of secularisation considers nature as an instrument of and arena for the human person's lordship. It was precisely this idea of creation that gave the human person the freedom vis-à-vis nature that made it possible to subjugate it and to use it for one's own ends (Hafstad 1995:105); hence, his suggestion that we need a theology that is not captured by static societal orders and the view of nature as a mere resource for human survival (106).

Nilsson (1995:117) advises that theology must start with the First Article of the Creed before it addresses the gospel. After properly situating creation within the First Article, he is convinced that the Second and Third Articles would follow. Johnsen (2009:112) concurs when he points out that, in particular, the Third Article has been neglected. He asserts that here the one, catholic and apostolic church and the communion of saints are understood within the context of the wholeness of creation. He is convinced that this way of understanding the Third Article will also help us resolve the tension that exists between the work of the Spirit in creation (Gen 1:2, Ps 104:30) and the work of the spirit related to Christ and the church. The communion of saints crosses all boundaries of time - those in the past, and in the present as well as future generations whose very possibilities are put at risk by the ecological crisis. Thus, a creative theology of creation must include all the three articles, and for the Triune God is intimately related with all of creation (LWF 2009:17). In other words, God is essentially relational, not an autonomous God but God-in-communion. According to LWF (2009):

The purpose of Trinitarian theology is not to define God or God's 'substance', but to describe the whole, interrelated gracious movement of God who seeks communion - intimate relationship - with what God has created. Creation is far more than just a backdrop for God's main redemptive activity in human history. It is the redemption of all creation that is at stake (Rm 8), not redemption from creation. (p. 19)

Creation, preservation and redemption are a single project of God and not three different projects. Through this project, God is giving birth to a world God intends to make good again. We need a theology of creation that will be comprehensive and inclusive than a mere theology of redemption. We would then be able to move from domination to stewardship to co-existence and partnership between the human species and the rest of creation (Huang 2013:16). The church year portrays for us the relationship of the Trinity to creation in the following manner (LWF 2009):

At Christmas, 'heaven and nature sing', as a bright star in the heavens is linked on earth with a lowly manger. On Good Friday, 
God is revealed in the One who suffers and dies with all creation, and at Easter, heaven and earth exult with the living God. At Pentecost, the wind of the Spirit blew from heaven, empowering those in the early church to communicate across their earthbound differences. (p. 20)

The Holy Spirit cannot be exhausted; it is God's ever-creative power and it is life-bestowing force of creation and re-creation. It is therefore God's agent of transformation in the world. McDonagh (1986) puts the agency of the Holy Spirit as follows (McDonagh 1986):

She is the principle of communion, binding all reality together. The Holy Spirit is the source of all unity. All attraction, all bonding, all intimacy, and communion flows from the Spirit. Each of these relationships is sacred to the Spirit. In her all the whole universe is linked together in one nurturing, enveloping embrace. She is the one who inspires all faithfulness and creativity - which are the signs of true bonding and intimacy. From her comes the urge to heal what is broken, re-unite what is separated, and re-create the face of the Earth. (p. 119)

God's presence in creation should reinforce our belief in God who is involved and cares about creation. Few aspects are looked at: (1) Incarnation: it is the clearest example of how God takes creation seriously. In Jesus of Nazareth, '... divinity and humanity, heaven and earth are brought together' (LWF 2009:20). All of creation is the abode of God. 'God is neither to be seen nor sought behind creation nor inferred from it, but only recognised in and through it. The cross reveals how radically God is immanent in creation' (LWF 2009:18-19). Incarnation means God values creation for its own sake. God does not transform it into something different other than what it is, God's own creation (Jn 1:11). God is to be encountered here on earth taking place in the midst of the natural world, in death, pain, suffering and so on, and that is the message of the cross. The cross is also a ' $\mathrm{No}^{\prime}$ to the sinful world. The cross is the exclusive criterion for revealing the God whom we already encounter in the vessels of creation (LWF 2009:22). As Zachariah (2009) aptly puts it:

The crucified God, whom we meet at the cross, is present in our life stories, even as we go through similar experiences due to climate change and other environmental crises. Incarnation is God's embracing of the material world. Redemption vision seen by John on Patmos is not a rescue mission of the saved souls, but rather the vision of a redeemed earth. The Church is called to witness to the in breaking of this vision in the here and now. (pp. 86-87)

The cross exposes systemic sin by opening our eyes to who we are as participants in the dehumanisation of our neighbour and degradation of creation. In this way, the cross unleashes moral power to fight the forces that are exploiting and abusing the earth. In our brokenness and bondage to sin, the cross makes us realise to the saving, healing and liberating Christ (Moe-Lobeda 2009):

God's presence in the depths of our brokenness means that God is present with grace even there where we are perpetrators of tremendous violence against others. God is present even if we continue with that violence, and even if we have no awareness of God's presence and no faith that God is present'. (p. 153)
And yet, the cross reveals us to be bearers of indomitable love according to Moe-Lobeda (2009:154). God's love is experienced in a unique and special way in the cross (McDonagh 1986):

The God he reveals to us is not some immutable, primary cause beyond the flux of the Earth and unmoved by suffering and pain. $\mathrm{He}$ is God who is passionately involved in his creation and wishes to see it flowering. (p. 119)

The more promising note is that the cross ends in resurrection.

(2) Sacraments: Protestantism recognises only two sacraments: baptism and the Eucharist. Sacraments foreshadow God's new creation. They become effective signs of hope for a crisis plagued creation. In baptism, water of nature is used to authenticate God's appreciation of nature and so the Eucharist by making use of wine and bread as products of the earth. God's grace is imparted through the elements of water, bread and wine (Mortensen 1995b:21-23). Water used in baptism symbolises the cleansing, purifying effect for the individuals, but most importantly, it symbolises new life. It is acceptance into the new community, the church of Christ that was created at Pentecost. However, McDonagh (1986:170-171) asks an ethical question as to whether our polluted water could still be perceived as life-giving. The Eucharist is celebrated as the Bread of Life and McDonagh still challenges us to ask ourselves as to how we can eat the Bread of Life in good conscience when two-thirds of the world population do not have regular meals. In fact, more than 1000 million people globally are starving with this number increasing at a phenomenal rate (p. 171). But Hefner (1995:129) is more optimistic when he says that sacramentally, real bread, real wine and real water understood with the promises attached to the sacraments can be vehicles for actualising the grace they portray. Lutheran World Federation comes even stronger when they say that through sacraments, God's promises become tangible through the elements of creation (LWF 2009):

We are redeemed by God not apart from but through what is created. We have been washed in waters of redemption in baptism and fed with the bread and wine of Holy Communion.

Through these Sacraments, the life-sustaining power of God's promises is effected in us, as a foretaste of the feast to come. (p. 25)

God is indeed everywhere in creation. Boff (1995:49) puts it emphatically that through the Holy Spirit, God dwells in the cosmos and in the human heart. He says everything is a manifestation of life. 'This life takes a thousand concrete forms, from the primitive movement from the original matter/energy, to its self-conscious expression in human beings' (1995:49). This explosive energy is expressed as the Holy Spirit, Creator par excellence. It is found everywhere and in all things. It is the Lord and giver of life. It empowers leaders, men and women. It is constantly the structure of the cosmos. He further states that Christianity also believes in the cosmic presence of the risen Christ, who is active in the process of evolution. He indwells creation and the cosmos has become his temple (p. 49). Considering what he says 
about the presence of the Holy Spirit, Boff (1995:50) suggests what he calls, 'Christian Pan-en-theism', meaning that everything is in God and God is in everything. He is quick to make the difference between pantheism and panentheism. Pantheism says everything is God and that primordial energy, atoms, stones, mountains, stars and human beings form part of the deity. All of these things are but different manifestations of the same unique substantial reality, which is God. Panentheism, however, starts from the distinction between God and the creature, and even maintains the relation between them. The one is not the other. Each one of them has his or her or its own relative autonomy, yet is always related. Not everything is God, but God is in everything. And then, vice versa, everything is in God. We are only through God and we move only through God because we are always in God, for indeed, as Acts 17:28 says, 'It is in him that we live and move and have our being' Boff (1995:50-51). He believes that panentheism gives rise to a new integrative and holistic spirituality that can unite heaven and earth (Boff 1995:51).

Pre-industrial societies and indigenous peoples in Africa, Asia and Latin America have been very close to nature and that is what panentheism is all about (Conradie 2009:42). It is unfortunate that these indigenous people's religion was called 'animist' by Western Christian missionaries, meaning that they worshipped God's creation rather than the Creator. Even with what the missionaries called ancestor 'worship', it was not so. Ancestor veneration is a more appropriate description of African religion. Ancestors were and are regarded as mediators between God and the living. The Sami, who are the indigenous people of the northern Scandinavia and the Kola peninsula in Russia, believe that creation has a voice and personality and if this voice was listened to, we would not be in this catastrophic situation (Johnsen 2009:101). Indeed, indigenous cultures relate to nature in an organic and relational way rather than in the mechanical way, where rationality rules supreme. Human life is of course valuable and sacred but a balance had to be struck where other forms of life would not be sacrificed as a matter of course (LWF 2009:20). Joseph (2013b:25) believes that from such cultures and traditions that are regarded as illiterate, the forest dwellers, traditional farmers, traditional fisher people and others have the wisdom to live in a harmonious relationship with nature.

Another dynamic that must be included in our discussion of the Trinitarian theology of creation is the cosmic dimension of redemption. How are we to understand, for example, Romans 8:22, Colossians and Ephesians 1? For sure, when we injure creation, it groans in anticipation of redemption. But as Boff (1995:47) puts it, redemption does not connote replacement but a recovery. It is not a substitution of this creation with another. This very creation that is bleeding needs bandaging, healing and restoration. God's word and everything that exists exist in relation to creation and serve its recovery. Huang (2013:13) complains that although the theological foundation of Christianity is the Triune God, when it came to soteriology, salvation has always been directed exclusively towards the human species. But God's intention is that all creation, and not only humans, should flourish. Here, we notice that the cosmic dimension of Christ's saving act is broadened quite significantly from that of human beings to that of the whole creation from before the dawn of time. The fullness of God comes to dwell bodily in creation: the powers of this world are put in their place, and broken relationships throughout creation are restored and reconciled.

Isaiah 65 and 66 promise creation of new heaven and new earth and so does Revelation 21. 'It is redemption of all creation that is at stake ( $\mathrm{Rm} 8)$, not redemption from creation' (LWF 2009:19). Mortensen (1995a:25-37) after discussing several approaches to tackling the environmental crisis arrives at a suggestion that he calls protological-eschatological approach. Protologically, Christian notion of creation with an attitude marked by respect and reverence of creation brings back nature to the centre of theology, and to the notion of the Cosmic Christ and eschatologically, there should be an environmentally sensitive Christian vision that reaffirms God's promise and fidelity as envisaged in Isaiah 11 and Revelation 21. The Bible does recognise the imperfection of the present creation and looks forward to a reshaped and transformed one in future.

\section{Conclusion}

We must understand that climate change has implications and consequences for human rights, gender justice and environmental justice (Stueckelberger 2009:47-62). If we were to adopt the proposed Trinitarian theology of creation, one is convinced that the balance and the equilibrium as well as the harmony with which the cosmos was created ex nihilo with God being the sole creator (Pietrantonio 1995:61-63; Hefner 1995:128) and humans as co-creators would somehow be restored. It will not be restored to its former glory, but rehabilitation of creation is still possible. We will at least be pulled back from the precipice as we strategise on the way forward. We will, as humans, have to collaborate. Religion, science and culture as well as politics, business and industry need to work together locally and globally to prevent more damage to creation, help with mitigation efforts and help especially the poorest of the poor, particularly in the South to adapt to the prevailing horrible conditions. This theology suggests for us a more wholesome and holistic way that would facilitate co-existence for all creatures in that complex web of interconnectedness and interrelatedness as well as interdependencies.

\section{Acknowledgements Competing interests}

The author declares that they have no financial or personal relationships which may have inappropriately influenced them in writing this article.

\section{Author's contributions}

R.T.H.D. is the sole contributor to this research article. 


\section{Ethical considerations}

This article followed all ethical standards for carrying out research without direct contact with human or animal subjects.

\section{Funding information}

This research received no specific grant from any funding agency in the public, commercial or not-for-profit sectors.

\section{Data availability statement}

Data sharing is not applicable to this article as no new data were created or analysed in this study.

\section{Disclaimer}

The views and opinions expressed in this article are those of the author and do not necessarily reflect the official policy or position of any affiliated agency of the authors.

\section{References}

Bloomquist, K., 2009, 'Introduction', in K. Bloomqist (ed.), God, creation and climate change, pp. 5-9, Lutheran University Press, Minneapolis, MN.

Boff, L., 1995, Ecology and liberation: A new paradigm, Orbis Books, Maryknoll, NY.

Boff, L., 2008, Essential care: An ethics of human nature, Baylor University Press, Waco, TX.

Conradie, E.M., 2009, 'Theological resources for responding to climate change: An overview', Missionalia 37(1), 33-52.

Hafstad, K., 1995, 'Reasons and foundations for an Ecumenical theology of salvation', in V. Mortensen (ed.), Concern for creation: Voices on the theology of creation, Tro and Tanke, pp. 103-114, Svenska Kyrkans Forskningsråd, Uppsala.

Hefner, P., 1995, 'Beyond exploitation and sentimentality: Challenges to a theology of nature', in V. Moretensen (ed.), Concern for creation: Voices on the theology of Creation, Tro and Tanke, pp. 119-141, Svenska Kyrkans Forskningsråd, Uppsala.

Huang, P.H., 2013, 'Whom to blame? An enquiry of the theological roots of ecological crisis and the challenges of Christian higher education in Asia', Theologies and Cultures X(1), 8-24.
Johnsen, T, 2009, 'Listen to the voice of nature: Indigenous perspectives', in K. Bloomquist (ed.), God, creation and climate change, pp. 101-113, Lutheran University Press, Minneapolis, MN

Jon-Ji, W., 1995, 'Quest for the integrity of creation', in V. Mortensen (ed.), Concern for creation: Voices on the theology creation, pp. 77-86, Tro and Tanke, Svenska Kyrkans Forskningsråd, Uppsala.

Joseph, M.P., 2007, 'Editorial', Theologies and Cultures IV(1), 5-7.

Joseph, M.P., 2013a, 'Editorial', Theologies and Cultures X(1), 5-7.

Joseph, M.P., 2013b, 'The economy of death and the theology of redemption', Theologies and Cultures X(1), 25-48.

Lonning, P., 1995, 'Creation - How it became an Ecumenical challenge', in V. Mortensen (ed.), Concern for creation: Voices on the theology of creation, Tro and Tanke, pp. 39-47, Svenska Kyrkans Forskningsråd, Uppsala.

LWF, 2009, 'God, creation and climate change: A resource for reflection and discussion', in K. Bloomquist (ed.), God, creation and climate change, pp. 13-26, Lutheran University Press, Minneapolis, MN.

Martin-Schramm, J.B., 2009, 'Human rights and climate change', in K. Bloomquist (ed.), God, creation and climate change, pp. 33-46, Lutheran University Press, Minneapolis, MN.

McDonagh, S., 1986, To care for the earth: A call to a new theology, Cassell Publishers Ltd., London.

Moe-Lobeda, C., 2009, 'Cross, resurrection and the indwelling God', in K. Bloomquist (ed.), God, creation and climate change, pp. 145-158, Lutheran University Press, Minneapolis, MN

Mortensen, V. 1995a 'From a liberated to a reconstructed creation', in V. Mortensen (ed.), Concern for creation: Voices on the theology of creation, Tro and Tanke, pp. 25-37, Svenska kyrkans forskningsråd, Uppsala.

Mortensen, V., 1995b, 'Towards a viable theology of creation', in V. Mortensen (ed.) Concern for creation: Voices on the theology of creation, Tro and Tanke, pp. 9-23, Svenska kyrkans forskningsråd, Uppsala.

Nilsson, G. 1995, 'Theology of creation - A challenge to church and society' in V. Mortensen (ed.), Concern for creation: Voices on the theology of creation, pp. 115-118, Tro and Tanke, Svenska kyrkans forskningsråd, Uppsala.

Northcott, M.S., 2007, 'Anthrogenic climate change: The moral and theological case for environmental rights', Theologies and Cultures $1 \mathrm{~V}(1)$, 59-86.

Pietrantonio, R., 1995, 'God is the sole creator and lord', in V. Mortensen (ed.), Concern for creation: Voices on the theology of creation, Tro and Tanke, pp. 61-75, Svenska kyrkans forskningsråd, Uppsala.

Rossing, B., 2009, 'God's lament for the earth: Climate change, Apocalypse and the Urgent Kairos Moment', in K. Bloomquist (ed.), God, creation and climate change, pp. 129-143, Lutheran University Press, Minneapolis, MN.

Stueckelberger, C., 2009, 'Who dies first? Who is sacrificed first? Ethical aspects of climate justice', in K. Bloomquist (ed.), God, creation and climate change, pp. 47-62, Lutheran University Press, Minneapolis, MN.

Zachariah, G., 2009, 'Discerning the times: A spirituality of resistance and alternatives', in K. Bloomquist (ed.), God, creation and climate change, pp. 75-91, Lutheran University Press, Minneapolis, MN. 